\title{
RUSSIAN FOREIGN POLICY IN CENTRAL ASIA: METHODS OF SOFT AND HARD POWER
}

\author{
A.N. Ospanova, O.I. Rakhmatulin \\ L.N. Gumilyov Eurasian National University, Kazakhstan, Astana, \\ e-mail:Rakhmatulin-os@mail.ru
}

Russia's foreign policy in Central Asia from the point of view of soft and hard power concepts is considered. Foreign policy is an important element of the state apparatus, which is becoming increasingly important in a globalizing world. Integration at different levels requires the search for increasingly new and effective methods of foreign policy interaction. On the example of soft and hard power strategies, an analysis of the methods of Russia's foreign policy in the Central Asian region is conducted. The article analyzes the possibility of searching for new models of cooperation. This region is selected based on historical features of the relationship both in the times of the USSR, and earlier. In addition, the countries of the region actively cooperate and interact in political, economic, energy, social, and other fields. All this causes the existence of the basis for the existence of mechanisms of soft, hard power in Russia, as one of the most interested party in participating in the processes taking place in the region.

Thus, Russia uses the opportunities and advantages of spreading Russian as one of the main instruments of soft power. There is also a military political presence in the region within the framework of mutually cooperative relations. All this allows us to promote our foreign policy and to coordinate with other countries in this direction.

Keywords: foreign policy, soft power, hard power, Russia, Central Asia, language, culture, army.

\section{ВНЕШНЯЯ ПОЛИТИКА РОССИИ В ЦЕНТРАЛЬНОЙ АЗИИ: МЕТОДЫ МЯГКОЙ И ЖЕСТКОЙ СИЛЫ}

\section{А.Н. Оспанова, О.И. Рахматулин}

Евразийский национальный университет им. Л.Н. Гумилева, Казахстан, Астана, e-mail:Rakhmatulin-os@mail.ru

Рассматривается внешняя политика России в Центральной Азии с точки зрения концепций мягкой и жесткой силы. Внешняя политика-важный элемент государственного аппарата, который становится все более значимым в глобализирующемся мире. Интеграция на разных уровнях требует поиска 
все более новых и эффективных методов внешнеполитического взаимодействия. На примере стратегий мягкой и жесткой силы проводится анализ методов внешней политики России в регионе Центральной Азии. В статье анализируется возможность поиска новых моделей сотрудничества. Данный регион выбран исходя из исторических особенностей взаимоотношений как во времена СССР, так и более ранних. Помимо этого страны региона активно сотрудничают и взаимодействуют в политической, экономической, энергетической, социальной и других областях. Все обусловливает наличие основ для существования механизмов мягкой и жесткой сил России как одной из самых заинтересованных сторон в участии в процессах, происходящих в регионе.

Таким образом, Россия использует свои возможности и преимущества распространения русского языка как одного из главных инструментов мягкой силы. В регионе также имеется военно-политическое присутствие в рамках взаимовыгодных отношений на основе сотрудничества. Все это позволяет продвигать свою внешнюю политику и конкурировать с другими странами в этом направлении.

Ключевые слова: внешняя политика, мягкая сила, жесткая сила, Россия, Центральная Азия, язык, культура, армия.

\section{Introduction}

The study of this region is relevant in connection with the interest of world powers towards Central Asia. Today the CA region is not only a trade and economic market, with huge reserves of energy and mineral resources, but also a «bridge» between East and West. But there is also a danger of spreading religious extremism. With each study of the history and processes taking place between the countries of the former USSR, in particular the countries of Central Asia and Russia, studies of the evolution of relationships are especially interesting. As after the severing of ties, new ones began to form. Every year new spheres of cooperation are being created. Today, the countries interact not only on the basis of bilateral relations, but also within the framework of the Eurasian Economic Union, the Shanghai Cooperation Organization, the Collective Security Treaty Organization, and so on. Thus, active foreign policy activities are maintained both from Russia and in its direction.

The authors use historical, systemic and comparative approaches to assess the mechanisms of foreign policy in order to achieve their goals.

The novelty of the work is, first of all, the need to continue research in this direction. In the opinion of the authors, the necessity is explained by the fact that consideration of a single foreign policy course, through the prism of the unit, on methods of soft and hard power, and possibly in the future use of other new approaches. Also it allows to look at current events from a new perspective. Particularly noteworthy is the comparison of the mechanisms for the implementation of foreign policy strategy. 


\section{Methods}

Sources for writing the work were monographs on the concept of «soft and hard power», scientific articles, reports, reviews, official statistics, which generally allowed to highlight the main aspects of the article.

When studying this problem, the authors based on factual, documentary and historical material used in specific studies. Various methods were used:

1) with the help of an analytical method, the main factors of the organization of foreign policy in Central Asia are considered;

2) on the basis of a comparative method, the basic mechanisms for implementing foreign policy have been studied and analyzed;

3) within the framework of the historical method, the causes, main events and the legal framework in the field of foreign policy of the Russian Federation were investigated.

\section{Results}

Summarizing the results of our research work, we note that during the period of building its foreign policy, Russia has managed to use cultural and historical ties with the countries of Central Asia in the field of the development of science and the spread of the Russian language. There are such organizations as «Rossotrudnichestvo» «Russian world», in the field of education and science, the activities of the AMGorchakov Foundation, which organizes conferences, roundtables, for students and young scientists, are celebrated. In addition, the opening of joint educational institutions plays a special role in this direction, which is basically a good basis for promoting Russian science and the role of the Russian language in scientific communication. Thus, exerting its influence on new generations, not caught the period of the USSR. This allows Russian influence to remain relevant for every younger generation, becoming more attractive to the masses. On the other hand, the existence of soft power institutions and mechanisms does not guarantee Russia success in this direction, since the organization of work requires tremendous effort, a technical and humanitarian base that translates into large financial investments. For Russia, if there are internal unresolved issues in the sphere of social policy and economic problems. And also, since the region of Central Asia is not the only important direction in the external political strategy of the Russian Federation, it is not the priority to work on organizing soft power in Central Asia. That is, the current level of impact of Russia's soft power in Central Asia has not yet reached the mark of effective returns and results, which means that Moscow can continue and strengthen this course.

Speaking about the hard power in Russia's foreign policy in Central Asia, everything is also not unique here. On the one hand, on the territory of the countries of the region there are signs of hard power, these are military bases, equipment, soldiers, auxiliary military-strategic structures. But on the other hand, this does not fully correspond to the traditional definition of hard power. Because there is no explicit bonus of these resources for their intended purpose. At the same time, the activities of these units demonstrate the presence of Russia's military power in Central Asia. 


\section{Discussion}

Unlike the last centuries, modern states have learned to widely use not only military, but also peaceful means of promoting foreign policy. Widely known traditional military-political methods, which have received the name of hard power, are gradually replaced by elements of a more flexible policy, today labeled soft power.

Especially often the methods of hard power were used during the two world wars and the Cold War. Today, the use of hard power is somewhat limited by the existence of international agreements, rules, political and economic organizations. Thus, any aggressive initiative in foreign policy can be subject to world criticism and countermeasures. Against this backdrop, special attention was given to the soft power strategy. This term was introduced in 1990 by Professor Joseph Nye, who in his books «Bound to Lead: The Changing Nature of American Power» (Joseph Nye,1990) and «Soft Power: «The Means to Success in World Politics» (Joseph Nye,2004) argued that language and culture play a key role in international relations, influencing politics and business relations.

«Soft power» is a strategy that allows different sides to want, and strives for the same results. But this does not mean coercion or any influence. The main emphasis is on using techniques of persuasions, beliefs, arguments, facts and other «soft methods» with the aim of attracting to mutual cooperation. That is, in this way, attractiveness becomes the key word here. Although speaking of application in foreign policy, it can also be understood that promotion of one's interests.

Speaking of «hard power» it is necessary to understand that its conceptual difference consists in coercion, and the promotion of its interests on the basis of the military economic power of the determining party. This strategy is relevant in the modern world. When states seek to protect sovereignty and interests from terrorist organizations capable of aggressive military and subversive actions.

The central concept in any strategy is, first of all, power or strength. At the same time, military and economic aspects belong to the hard power. And soft power is based on such pillars as culture, political ideology and foreign policy. If the first two can be attributed to historical components, then foreign policy to a more subjective and special case. Dependent on the actions of official bodies of the state.

The common basis for both hard power and soft is that they both can lead to the attainment of the tasks set, influencing the behavior of other participants in international relations. The only difference is that different resources and tools are used. So hard power resorts to the strength of its economy and army, and soft power uses cooperation and coordination of foreign policy measures, involving a wide range of participants in its impact, and all the while is formed on the basis of values and cultural features. Another distinguishing feature of the soft power is its relative independence from the state apparatus itself, in comparison with the hard power. Which, in turn, is much more tied to political actions and completely depends on them. On the one hand, it makes it easier to control the mechanism for carrying out «hard measures» than to follow the «soft processes», but on the other hand, the latter are less likely to meet official barriers, because the ways of their spreading become society. 
Nevertheless, the strategy of hard power does not lose its relevance to foreign policy, which is connected with geopolitical and economic interests, as well as with the issues of state security.

This can be confirmed by an annual increase in military spending, for example, in Russia: 2.8129 trillion. rubles in 2013, 3.2505 trillion rubles in 2014, 4.0474 trillion rubles in 2015 (SIPRI Military Expenditure Database, 2016) 3.945 trillion rubles in 2016 and 3,776 trillions. rubles in 2017 (SIPRI: Russia increases military spending despite financial difficulties, 2017).

Analyzing Russia's foreign policy in Central Asia in this article, it can be noted that Russia's interest in Central Asia comes primarily from the desire to maintain its political and economic influence in the region. The greater the influence of Russia's foreign policy in the Central Asian region, the more political weight Russia has on the world stage. The weakening of ties with the Central Asian states can lead to the fact that the Russian influence will be replaced by another, threatening the internal stability of the Russian Federation and the region as a whole. In addition, the importance is added by the fact that stable strategic relations with the countries of the region facilitate access to markets and new areas of cooperation with China, India, Iran, etc. It can be noted cooperation in the framework of the Shanghai Cooperation Organization. On the other hand, relations with Central Asia for Russia are important in relation to their own internal interests. This provides access to the market where Russian goods come in, realizing a significant part of the export of food products, machinery, light industry, etc. On the other hand, large flows of labor migrants arrive in Russia, which also significantly affects the country's economy. Speaking about migration processes, it should be noted that if official migration flows affect the economy, the informal ones additionally become security issues for Moscow. In general, the security policy of the Russian Federation and Central Asia are linked by such areas as the threat of penetration by radical terrorist organizations that take place in the Middle East. Also, the drug traffic that begins its journey settles both in the countries of Central Asia and in Russia, and in addition it also finds ways to enter the countries of Europe. Thus, this problem becomes common for the region.

In this way, it can be noted that regional security issues are extremely important both for Russia and for the countries of Central Asia Concept of foreign policy of the Russian Federation,2016). Due to its military and political potential, Russia is to some extent a guarantor of security in the region. And this is ensured by using the military-political potential of Russia, as well as military bases and cooperation within the CSTO framework.

Military bases are one of the part of backbone for military operations greatly increasing its success. Thus, the largest military base in Russia in Central Asia is located in Tajikistan (201 military base), the number of 5.9 thousand military, and by 2020 is planned to increase to 9 thousand (Małgorzata Krakowska, 2017). Also in Tajikistan is the opto-electronic complex «Window» («Nurek») and space monitoring systems, which make it possible to detect space objects at altitudes of up to $40,000 \mathrm{~km}$. The presence of military objects is important both for Russia and for Tajikistan itself because of its proximity to Afghanistan, as well as in connection with threats to the country's internal stability (Abdujalil Abdurasulov, 2015). 
Another strategically important object for Russia is the Baikonur cosmic complex in Kazakhstan, which remains the first and largest cosmodrome in the world, where only in 2015 there were 18 launches from 86 worldwide (Sofia Pale, 2015), 13 launches in 2017 (Baikonur remained the leader in the number of launch vehicles in 2015, 2015). In addition, in Kazakhstan there is a separate regiment of transport aviation in the city of Kostanay, the test site of Sary-Shagan and other objects.

In Kyrgyzstan, there are such objects as the 338 communication center of the Russian Navy capable of conducting radar reconnaissance of the terrain, as well as the test base of anti-submarine torpedo weapons on Issyk-Kul Lake. But the main military object for Russia in this country is the joint aviation base of Kant. The significance of this base lies in the possibility of flying aviation both in the Central Asia region and the Middle East. It is noteworthy that until 2014, $30 \mathrm{~km}$ from Kant, was the center for transit transportation of the US Air Force - Manas.

It should be noted that the Kant airbase remains the site for the dislocation of aviation of the Collective Rapid Response Force (CBDN) in Central Asia within the framework of the CSTO (Bobokulov I., 2012). Cooperation within the framework of the Collective Security Treaty Organization (CSTO) is another important aspect of the Russian foreign policy in Central Asia. On the one hand, the organization is called upon to unite the military forces of states, together to confront threats to security (extremism, drug trafficking, military conflicts), and on the other hand it ensures the relevance of the military facilities of the Russian Federation in these countries.

The undoubted advantages of Russia's military technical potential for its foreign policy, both within the framework of the CSTO and for the two-way cooperation, is that the military forces of the Central Asian states are mostly technically equipped with military equipment of the USSR and modern Russia, which in turn leads to affection military complexes of Russian troops. And here opens a new aspect of the military-industrial complex of Russia, where the popularity of military equipment and its recognition as one of the best in the world, directly affects the increase in the attractiveness of the country as a whole. And this, in turn, is already one of the tasks of the «soft power» of the Russian Federation.

Russia has great potential for the development of its «soft power» in the republics of Central Asia. This is due to the common cultural values that prevailed in the period of the USSR and before it. Also, the spread of the Russian language as one of the international languages is one of the main instruments of soft power. So, for example, the status of the Russian language in Kazakhstan in accordance with Article 7 of Section 1 of the Constitution of the Republic of Kazakhstan «in official organizations and bodies of local self-government on an equal footing with Kazakh, the Russian language is officially used» (The Constitution of the Republic of Kazakhstan, 1995). In accordance with Article 10 of the Constitution of the Kyrgyz Republic in 2010, Russian has the status of an official language (The Constitution of the Kyrgyz Republic, 2010). In general, in the republics of the post-Soviet bloc, the overwhelming majority of residents speak or understand the Russian language. In addition, the popularity of the language is supported by widespread Russian media and Internet resources. 
Speaking about the official nature of the concept of «soft power» in Russia, it is necessary to note the article by V.V. Putin «Russia and Changing the World» in 2010. Where there was definitely a Russian interpretation of the notion of soft power. It was emphasized that the instruments of soft power serve foreign policy purposes, and that in combination these methods do not include the use of weapons. But also the importance of informational methods of influence is emphasized (Putin V.V., 2012).

Even before the «soft power» first appeared in the concept of the foreign policy of the Russian Federation in 2013, it was implemented by such organizations as the federal agency Rossotrudnichestvo, created in 2008, and the Russkiy Mir Foundation, established in 2007 Both organizations promote and popularize Russian culture and language, as well as interaction with compatriots (Shevtsova L. 2015). So, in Kazakhstan there are 4 centers of the Fund «Russian World»: in Astana, Ust-Kamenogorsk, Aktobe and Almaty. Kyrgyzstan has 3 centers in the cities of Osh, Bishkek, and Kant. In Tajikistan and Uzbekistan there are 4 centers of the «Russian World». Basically, these centers are established on the bases of universities and libraries (Information portal of the fund Russian world, 2018).

Representatives of Rossotrudnichestvo operate in all republics. On the organization's line in 2016 it was planned to allocate 300 quotas to Kazakh students in Russian universities. In 2015, the quota was 450, while in 2014 - only 200. And for more than 400 teachers of Kyrgyzstan, Uzbekistan and Moldova, teaching in Russian, seminars were held to improve the qualifications of teaching. Thus, these organizations are engaged in the popularization of Russian culture, organizing meetings, lectures, arranging cultural events, etc.

Central to all this is the educational process, because of its focus on the younger generation and the competent use of scientific and academic literature. At the same time, those who want to study will also have the opportunity to study at the branches of Russian universities, which are widely represented in Kazakhstan, Kyrgyzstan, Tajikistan and Uzbekistan. Among them there are such high schools as: Kazakhstan branch of M.V. Lomonosov Moscow State University. Lomonosov, Branch of the Baltic State Technical University «Voenmeh» them. D.F. Ustinov in Bishkek, the Russian-Tajik (Slavonic) University, a branch of the Russian Academy of Economics. G.V. Plekhanov and others. Through all these opportunities, students from Central Asian countries can study at Russian universities for free or for free. According to statistics, most of the foreign students in Russia are from Kazakhstan (53.809 people, or 28.8 percent), Turkmenistan (15.631, or 8.4 percent) and Uzbekistan (15.025, or 8 percent) (Rossotrudnichestvo announced the admission of foreigners for free education in Russian universities, 2016). The development of interrelations in the field of education leads to the development of relations as a whole between states. It works by the principle: the more people are connected with the culture of another state, the more they are loyal to it.

\section{The conclusion}

Based on the foregoing, we can say that the Russian «soft power» has a huge field to deploy its activities, which, of course, is a clear advantage over other countries claiming leadership in the region. At the same time, Russian capabilities do not guarantee success in 
advancing their foreign policy influence. This is due to the fact that the Russian «soft power» is not able to respond quickly and effectively to the challenges in regional relations. The advantage of this strategy is a deep approach to strengthening its influence through culture, which means it takes a longer time.

In turn, the methods of hard power are able to quickly turn the circumstances as necessary for Russia. The presence of military forces on the territory of the Central Asian states demonstrates the readiness of the Russian Federation to use them. However, with such a strategy it is extremely important to understand the boundaries and possibilities of its use, otherwise there is a danger of negative reaction and loss of one's positions. In addition, it is necessary to have economic capacities to support its military forces, which is also a difficult and expensive task. Russia today has the opportunity to combine «soft» and «hard» power and create its own «smart power», which some experts interpret as an uniquely more effective strategy in the modern world. But before that, it will be necessary to strengthen the country's economy, develop a unified, integrated strategy and withstand the competition of other states. What today is a challenge.

\section{REFERENCES}

Abdujalil Abdurasulov (2015). Russia strengthens its military presence in Central Asia. Available at: http://www.bbc.com/russian/international/2015/10/151016_cis_summit_kazakhstan (accessed 17 December 2017).

Baikonur remained the leader in the number of launch vehicles in 2015. (2015) Available at: http://www.kazpravda.kz/news/tehnologii/baikonur-ostalsya-v-liderah-po-chislupuskov-raket-nositelei-v-2015-godu/ (accessed 5 January 2018).

Bobokulov I. (2012). Strategic functions and prospects for foreign military presence in Central Asia. Central Asia and the Caucasus. Volume 15. Number 2. 2012. Pp. 112-120.

Concept of foreign policy of the Russian Federation. November 30, 2016. Available at: http://www.mid.ru/foreign_policy/news/-/asset_publisher/cKNonkJE02Bw/content/ id/2542248 (accessed 5 March 2018).

Information portal of the fund Russian world. Available at: http://russkiymir.ru/rucenter/ catalogue.php (accessed 28 December 2017).

Małgorzata Krakowska (2017). Russia is reducing the military budget, but continues to arm. Available at: http://inosmi.ru/politic/20171107/240704660.html (accessed 12 December 2017).

Nye, J. Bound to lead: the changing nature of American power. New York: Basic Books, 1990.

Nye, J. Soft Power: The Means to Success in World Politics. New York: Public Affairs, 2004.

Putin, V.V. Russia and the changing world, «Moscow News». 2012. Available at: http:// www.mn.ru/politics/78738.

Rossotrudnichestvo announced the admission of foreigners for free education in Russian universities (2016). Available at: http://sogdiana.tj/centralnyy-blok-1/3255-rossotrud- 
nichestvo-obyavilo-priem-inostrancev-na-besplatnoe-obuchenie-v-vuzah-rossii.html (accessed 28 December 2017).

Shevtsova, L. Forward to the past in Russia. Journal of Democracy. April 2015. Volume 26, Number 2. P. 26.

SIPRI Military Expenditure Database. Available at: https://www.sipri.org/databases/milex (accessed 20 November 2017).

SIPRI: Russia increases military spending despite financial difficulties.(2017) Available at: http://www.bbc.com/russian/features-39683307 (accessed 26 November 2017)

Sofia Pale (2015). Great problems of Tajikistan. Available at: http://ru.m.journal-neo. org/2015/10/17/bol-shie-problemy-tadzhikistana (accessed 17 December 2017).

The rocket starts from Baikonur in 2018.(2017) Available at: https://ru.sputniknews. kz/space/20171019/3539294/puski-raket-s-bajkonura-uvelichat-v-2018-godu.html (accessed 19 January 2018).

The Constitution of the Republic of Kazakhstan. Almaty, August 30, 1995. Available at: http://www.parlam.kz/ru/constitution (accessed 1 March 2018) .

The Constitution of the Kyrgyz Republic on June 27, 2010. Available at: http://www.gov. kg/?page_id=263\&lang=ru (accessed 1 March 2018). 